\title{
A Proposal for the Restoration of Job 34:26-30 in Elihu's Second Speech
}

\author{
ARON Pinker (MARYLAND, USA)
}

\begin{abstract}
Commentators found the unit Job 34:26-30, in Elihu's second speech, difficult to interpret and translate because of its thematic incoherence, abrupt style, and use of ambiguous terms. It has been generally assumed that the unit underwent some corruption in the historical transmission process. This paper attempts to restore a sound thematic flow to vv. 26-30 using standard text-critical methods. It is being shown that relatively few minor text-critical emendations allow to obtain a simple and coherent text, having a typical (for the Book of Job) 3:3 meter. The resolution of the difficulties in the unit is premised on the notion that the unit is focused on potentates that have lost their moral compass and God's reaction to their deeds. From this perspective, $v v .26-30$ fit contextually the larger unit in which it is embedded (vv. 16-30), which deals with God's righteous management of nations and people. Job's personal problem is addressed only indirectly. Job can deduce from Elihu's words that: his punishments indicate that he sinned; he is ignorant of God's ways and abandoned moral behavior; he has caused anguish to the destitute, which reached heaven; he cannot compel God to confront him; and, God works in mysterious ways. Elihu's message to Job is hard hitting, but it is not devoid of hope.
\end{abstract}

KEYWORDS: Job 34:26-30; Elihu's second speech; public punishment; Deus absconditus; divine sovereignty; timeliness

\section{A INTRODUCTION}

In vv. 26-30 Elihu states:

He strikes them down with the wicked

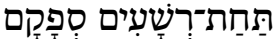

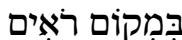

Where people can see,

Because they have been disloyal to Him

And have not understood any of His ways;

Thus He lets the cry of the poor come before Him;

He listens to the cry of the needy.

When He is silent, who can condemn?

If He hides His face, who will see Him,

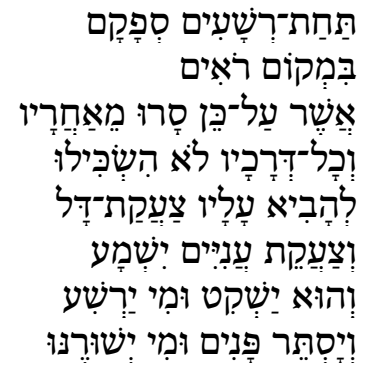

* Article submitted: 20/06/2016; accepted: 28/09/2016. To cite: Aron Pinker, “A Proposal for the Restoration of Job 34:26-30 in Elihu's Second Speech," OTE 29

(3) 2016: 550-580. Doi: http://dx.doi.org/10.17159/2312-3621/2016/v29n3a12 
When He is silent, who can condemn?

If He hides His face, who will see Him,

Be it nation or man?

The impious man rule no more

Nor do those who ensnare the people.

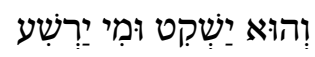

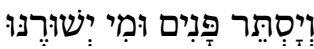

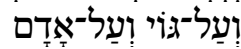

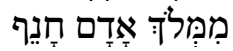

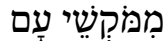

Even a casual reading of this well-known NJPS translation strikes one as being a collection of unrelated statements. The translation seems to assume that Elihu describes in vv. 26-30 what God did to the mighty (כָּבִּירִים), which were mentioned in v. 24, and where the word תָח has also been used (thus, intertextuality would imply thematic similarity). However, this would mean

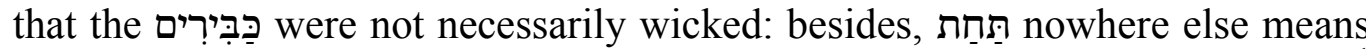

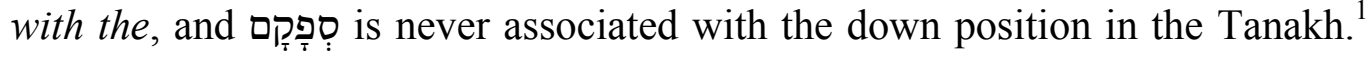
These are some of the difficulties in the first short verse. One might add that in

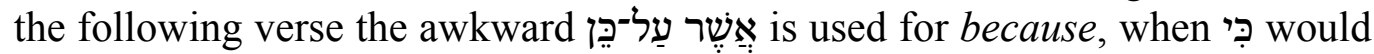
have sufficed. In the next verse MT has no word corresponding to Thus He lets. If Elihu wants to say that God can do whatever he wants, as is generally understood, then his argument would be strengthened by using opposites. However,

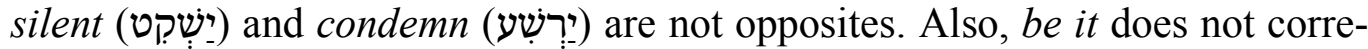
spond to Hebrew וְעַל. Finally, it is difficult to anchor the translation of the last verse in the MT.

The NJPS interpretation of v. 29 also raises some troubling thoughts. Andersen observes,

... verses 29f. are not satisfactory, and some have found in them a darker and more disturbing thought. Even if God is quite inactive, leaving evil unchecked, who can condemn? If He chooses to hide His face, who can make Him show it? ... The prophets were able to entertain the thought that the Assyrian was the rod of God's anger (e.g. Isa 10:5), and Habakkuk could think the same about the Babylonians. But they always added that these nations, despite such use by God, were fully accountable for their evil deeds, and would in due time pay for them. But this involves a historical stage, group guilt, and long spans of time, which are not used in the book of Job. This keeps the problem focused on the apparent injustice of God's treatment of one man, Job. ${ }^{2}$

Indeed, one might rightly question the relevance of Elihu's words to the Jobian context.

1 BDB, 1065a-1066a. The authors (1065b) note: "Peculiarly Jb 34:26 (si vera 1.) = as if they were, like; but text very dubious."

2 Francis I. Andersen, Job: An Introduction and Commentary (London: Inter-Varsity Press, 1976), 254. 
Driver and Gray believe that v. 26 in the MT is corrupt. ${ }^{3}$ They find that in v. 28 "the consequence being represented as the intention." In their opinion vv. 29-33 are

as a whole unintelligible, the details being, if not unintelligible, then (as in 29) very ambiguous, and the ambiguities, in face of the extreme uncertainty of the remainder, insoluble. In addition to its unintelligibility, the formlessness of much $(29 \mathrm{c}, 30,31,35)$ of the passage points to considerable corruption of the text. ${ }^{4}$

Pope says that vv. 28-33 "are replete with difficulty. LXX originally omitted them entirely. Modern critics have emended freely, with imagination and originality.",5

The purpose of this paper is to restore vv. 26-30 into a coherent unit using standard text-critical methods. It will be shown that such a restoration is possible making only minimal violence to the consonantal text. The restored text has a typical (for the Book of Job) 3:3 rhythmic structure, while securing an unforced sense. Elihu indirectly accuses Job of being wicked, but raises the hope that if Job has a valid case then it has been heard and would be in due time resolved.

The following section (B) presents a detailed analysis of a representative sample of exegetical studies in which the text under consideration has been addressed. In it, an attempt has been made to capture the challenges that the text presents, reveal the spectrum of views that exist, and identify the shortcomings of the exegetical efforts. In a first reading, the details, semantic technicalities, and range of sources might be somewhat distracting. A reader that is eager to become engaged quickly in the proposed solution would be welladvised to skip section $B$, continue with section $C$, and in a second reading return to section $B$.

\section{B ANALYSIS}

The translations/interpretations of the ancient versions and modern exegetes will now be considered. This analysis will illustrate the difficulties that the translators and exegetes faced, how they tried to overcome them, and the weaknesses of these efforts.

3 Samuel R. Driver and George B. Gray, A Critical Exegetical Commentary on the Book of Job, vol. 2, ICC (Edinburgh: T \& T Clark, 1921), 260.

4 Samuel R. Driver and George B. Gray, A Critical Exegetical Commentary on the Book of Job, vol. 2, ICC (Edinburgh: T \& T Clark, 1921), 300.

5 Marvin H. Pope, Job, AB 15 (Doubleday: Garden City, 1986), 259. 


\section{Ancient Versions}

Tov observes that: "The differences between the Septuagint (LXX) and the traditional Hebrew (Masoretic Text) stem from the Greek translator's free approach: the LXX rephrases and frequently streamlines ideas and verses in the MT, probably in response to the often verbose and repetitive Hebrew text." For vv. 26-30 the Septuagint has

${ }^{26}$ And he quite destroys the ungodly, for they are seen before him.

27 Because they turned aside from the law of God, and did not regard his ordinances, ${ }^{28}$ So as to bring before him the cry of the needy; for he will hear the cry of the poor. ${ }^{29}$ And he will give quiet, and who will condemn? And he will hide his face, and who shall see him? Whether it be done against a nation, or against a man also: ${ }^{30}$ causing a hypocrite to be king, because of the waywardness of the

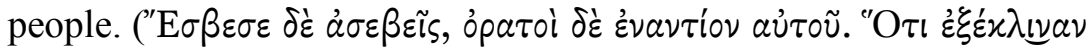

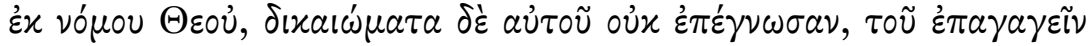

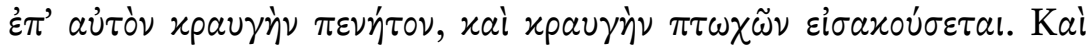

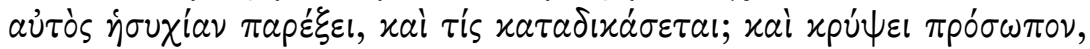

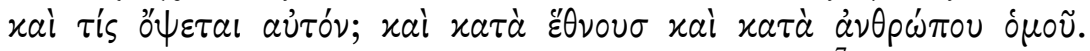

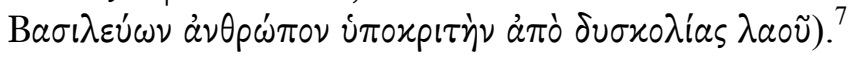

The Septuagint's translation ${ }^{8}$ does not render תח, in MT of v. 26, but has ידעכו in the preceding verse. ${ }^{9}$ It also attaches ספקסם phrases ספקם במקום ראים by "for they are seen before him" (ópatol dè żvavtiov

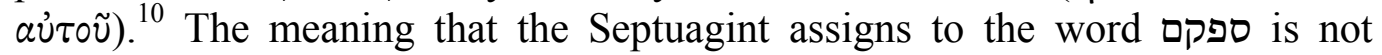

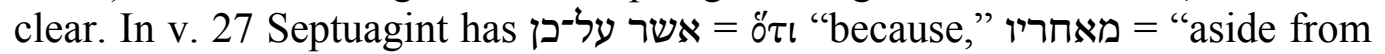

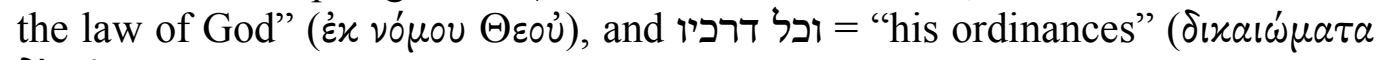
$\delta \dot{\varepsilon}$ a $\tau \dot{\tau} \tau \tilde{u})$. Dhorme notes that vv. 28-33 are

absent from Sahidic, marked with asterisk in Jerome, Syro-hexapla, and Colbertinus (with the exception of v. 32), did not exist in G

6 Emanuel Tov, "Job 34," in Outside the Bible, Ancient Jewish Writing Related to Scripture, vol. 1, ed. Louis H. Feldman, James L. Kugel, and Lawrence H. Schiffan (Philadelphia: Jewish Publication Society, 2013), 111.

7 Eduard Dhorme, A Commentary of the Book of Job (London: Nelson, 1967), 521. Dhorme notes that "It is in error that Colbertinus and Jerome mark with asterisk vv. 26-27, which in fact exist in Sahidic and are not marked with asterisk in Syro-hexapla. The text of Theodotion does not begin before v. 28."

8 Lancelot C. L. Brenton, The Septuagint with Apocrypha: Greek and English (London: Samuel Bagster, 1851; repr. Peabody: Hendrickson, 1987), 691. This translation is based on the Vaticanus version of the Septuagint.

9 Georg Beer, Der Text des Buches Hiob (Marburg: N.G. Elwert, 1897), 218.

10 Dhorme, Job, 521. Dhorme notes that Codex Alexandrinus has xai ópatoi

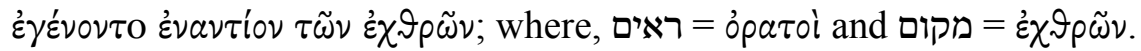


[Septuagint]. The present text of v. 28 is derived from Theodotion. ${ }^{11}$

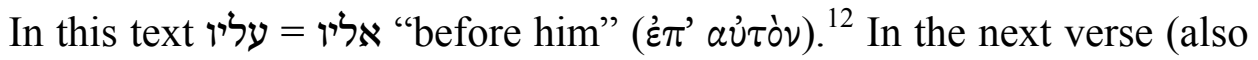

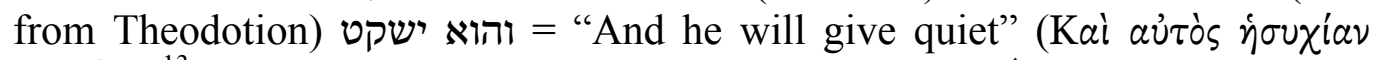
$\left.\pi \alpha \rho \varepsilon^{\prime} \xi \varepsilon l\right) .{ }^{13}$ Finally, in v. 30 Theodotion apparently reads ממליד = "causing to be

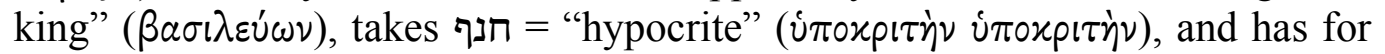

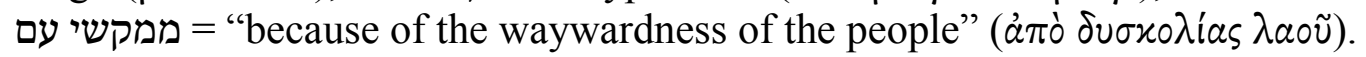

Targum's literal translation reads:

${ }^{26}$ Instead the wicked he stroke them in a place that can be seen.

${ }^{27}$ For therefore they turned from following him and all his ways they did not understand. ${ }^{28}$ To bring upon him the outcry of the poor and the cry of the destitute he will hear. ${ }^{29}$ And he will quiet and who will condemn him, and will remove his presence and who will see him, and he visits the guilt of both nation and individual. ${ }^{30}$ Appoints king a sycophant, because of snares among the people.

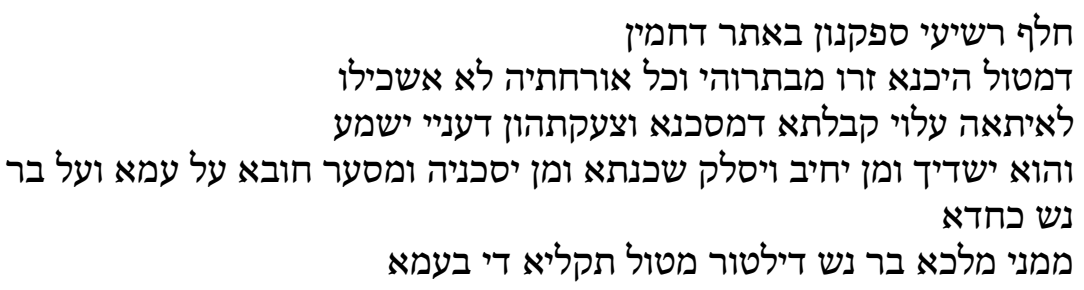

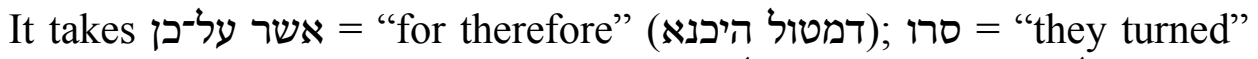

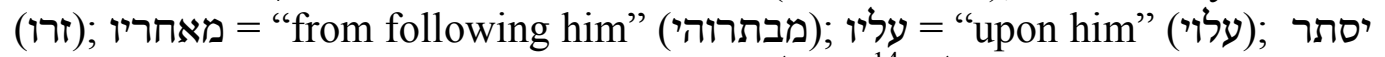

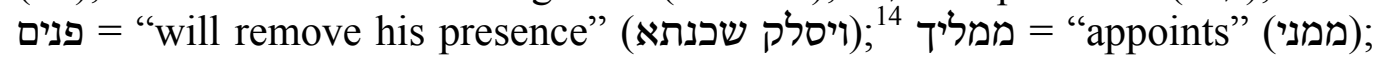

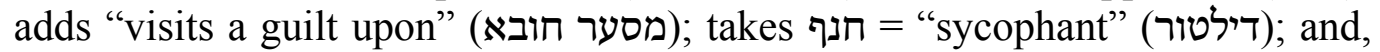

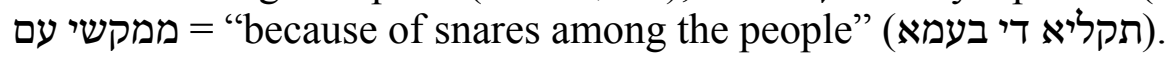

11 Dhorme, Job, 522-523. Verses 28-33 were omitted from the Septuagint till the time of Origen, and do not occur in the Sahidic version. Tov (Job 34, 114) conjectures that "The Greek translator removed these verses because the same ideas are presented in the preceding chapter (Job 33:14-33)."

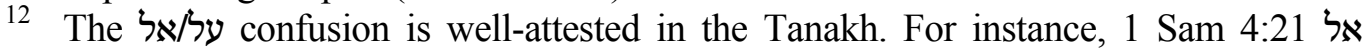

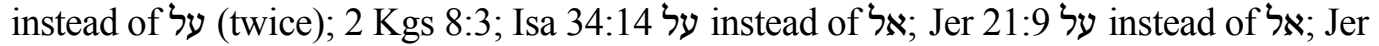

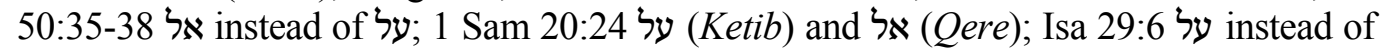

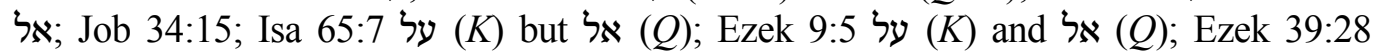
in some MSS (cf. Tanakh Koren [Jerusalem: Koren, 1983), 13

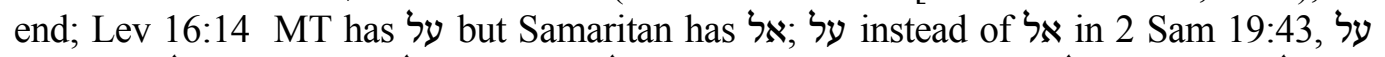

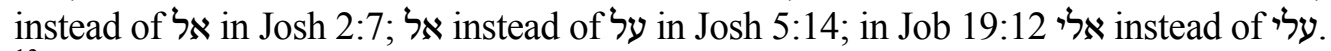

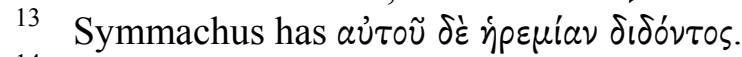

14 Pope, Job, 259. Pope notes: "The Qumran Targum reads [wyst]r 'npwhy mn ytybnh '[and should he hid]e his face, who could make him return.' The puzzling

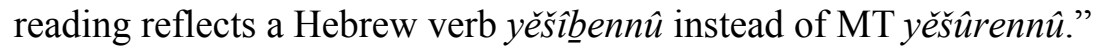


Peshitta paraphrases vv. 26-30, rendering:

${ }^{26}$ Their works shall be crushed under the weight of their wickedness in a land of terror; ${ }^{27}$ Because they turned aside from following him, and did not consider any of his ways. ${ }^{28}$ The prayer of the poor comes to him, and he hears the cry of the afflicted. ${ }^{29}$ When he forgives, who can then condemn? And when he turns his face away, who can forgive the people, or mankind altogether? ${ }^{30} \mathrm{He}$ sees to it that an impious and wicked man shall not reign over the people.

It apparently expands the text and attaches וידכאו ("shall be crushed") of

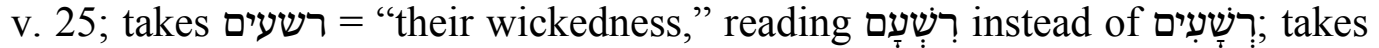

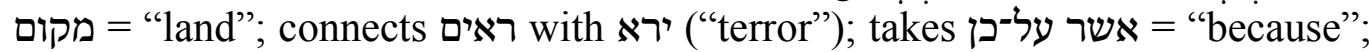

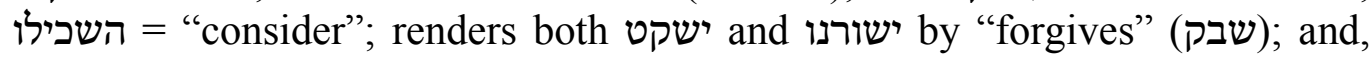
takes "shall not reign over the people."

Vulgate translates:

${ }^{26} \mathrm{He}$ hath struck them, as being wicked, in open sight. ${ }^{27}$ Who as it were on purpose have revolted from him, and would not understand all his ways: ${ }^{28}$ So that they caused the cry of the needy to come to him, and he heard the voice of the poor. ${ }^{29}$ For when he grants peace, who is there that can condemn? When he hides his countenance, who is there that can behold him, whether it regard nations, or all men? ${ }^{30}$ Who makes a man that is a hypocrite to reign for the sins of the people? (quasi impios percussit eos in loco videntium. qui quasi de industria recesserunt ab eo et omnes vias eius intellegere noluerunt. ut pervenire facerent ad eum clamorem egeni et audiret vocem pauperum. ipso enim concedente pacem quis est qui condemnet ex quo absconderit vultum quis est qui contempletur eum et super gentem et super omnes homines. qui regnare facit hominem hypocritam propter peccata populi). ${ }^{15}$

It takes תחת = "as, for" (quasi); רשעים = "being wicked" (impios); עליו = אליו "to him" (ad eum); והוא ישקט = "for when he grants peace" (ipso enim concedente pacem); ויסתר פנים = "When he hides his countenance" (ex quo absconderit vultum); ממלך = "who makes a man who is" (qui regnare facit); = "ממקשי עם = "for the sins of the people" (propter peccata populi).

15 This is the Douay-Rheims translation. Jerome has: 26. et extinxit impios et gloriosos coram inimicis suis, 27. quia declinauerunt a lege dei, et iustitias eius non cognouerunt, 28. ut perferatur ad eum clamor pauperis, et clamorem pauperum exaudiet. 29. Ipse quietem dabit, et quis poterit condemnare? abscondit faciem, et quis uidebit eum? et contra gentem et contra hominem simul. 30. qui regnare fecit hominem ippocritam propter peruersitatem populi. Cf. Carl P. Caspari, Das Buch Hiob $(1,1$ - 38,16) in Hieronymos's Uebersetzüng aus der alexandrinischen Version nach einer St. Gallener Handschrift (London: Luzac, 1893), 102. 
The variations between the Versions do not indicate that they translated from a different Vorlage than the MT. However, it is obvious that they struggled with the thematic coherence of the text before them.

\section{$2 \quad$ Modern Exegesis}

Modern exegetes assumed that in vv. 26-30 Elihu describes God's position with regard to a country's rulers. It is God who punishes these wicked publicly (v. 26), for deviating from the Godly path (v. 27), thereby causing anguish to the poor and destitute (v. 28). God's reaction to this behavior might be inaction or discontinuation of his grace to a collective or individual (v. 29), even the intentional appointment of an amoral individual as king (v. 30). However, most exegetes encountered difficulties in trying to reconcile between their particular perceptions of Elihu's argument and the MT.

Clines' relatively recent commentary on Job renders vv. 26-30 thus:

(26) He strikes them down for their wickedness, where all can see, (27) because they turned aside from following him, and had no regard for his ways, (28) so that they caused the cry of the poor to come to him - and he heard the cry of the afflicted. (29) If he is quiet, who can condemn him? If he hides his face, who can see him? Yet he rules over nations and individuals alike, (30) so that the godless would not govern, and a people should not be ensnared. ${ }^{16}$

Clines' translation, used as a current exegetical reference, assumes that:

beneath, in place of, instead of," but not "down"; for which the term מַטָָ is is used. Some commentators follow the Targum taking תחָת = "place." ${ }^{\prime 17}$ For instance, in Hirzel's opinion: "תחת ist Subst. und Accus. des Ortes, wie v. 24, 36:16, 40:12, Jes 5:8." "Ehrlich says: "תחת heist hier nicht 'unter,' sondern, ... 'wie' eigentlich 'als' wie dies zur Bezeichnung des Prädikatsnomens gebraucht wird."19 Similarly, Dhorme explains: "The word תחת 'under' also means 'in the place of" and derivatively, 'in guise of,' 'like.", ${ }^{20}$ In Budde's view, "תחת nicht 'unter, zwischen,' noch 'an der Stätte,' sondern nur 'anstatt' = 'als wenn

16 David J. A. Clines, Job 21-37, WBC 18A (Dallas: Word Books, 2006), 745.

17 Ludwig F. Melsheimer, Das Buch Hiob (Mannheim: Schwan, 1823), 70. Melsheimer renders v. 26: "Um Orte, wo einst Frevler wohten, Shlägt, wer sie sah, die Händ' zusammen." This is more of a paraphrase than a correct translation.

18 Ludwig Hirzel, Hiob (Leipzig: Weidmann, 1885), 205.

19 Arnold B. Ehrlich, Psalmen, Sprüche, und Hiob (vol. 6 of Randglossen zur hebräischen Bibel (Leipzig: J. C. Hinricks, 1918), 299. See commentary on v. 30:14.

20 Dhorme, Job, 522. One finds in Sir 30:25 שנות לב טוב תחת מטעמים. Cf. also August Dillmann, Hiob (Leipzig: Hirzel, 1891), 296. 
sie Frevler wären,' also etwa = כְ. ${ }^{, 21}$ Hahn understands תחת being multifaceted: "an der Stelle der Freveler, wie Freveler gestraft werden, und also als solche und wie solche.",22 Hitzig says: "auch kann תחת nicht für תחת הֶיוֹת gesagt sein. ... Also denken wir lieber an Stelle, Standort (36:16, Richt 7:21, Jes 5:8).,"23

Delitzsch explains: "תחת רשעים cannot signify: on the place of the evil-doers, i.e. in the place where evil-doers are punished (Hirzel,

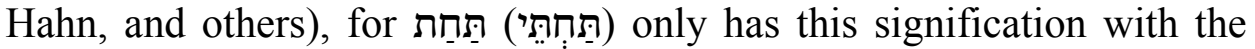
suffix (Hab 3:16); but not otherwise than: in the evil-doers' stead, taking them and treating them as such, as Jerome has correctly translated: quasi impios (comp. Isa 10:4, Jerome, cum interfectis)." ${ }^{24}$ Reichert says: "The preposition is used here in the unusual sense of 'as if they were.' Although they are men of high station, they meet the fate of the common תחת תחת "would imply that the כבירים nowhere else means like. The text must thus be at fault.",26

Budde notes that:

Bickell beseitigte die Schwierigkeit, indem er תָָ punktierte und als Subjekt hinter רשעים (zur Erklärung des Ausfalls besser hinter ergänzte: »sein Grimm zerbricht (Jes 9:3) die Frevler«. Damit wurde ספקם zu erwünschter Verlängerung von b frei. So für b auch Bickel. ${ }^{27}$

This approach is adopted by Driver and Gray, who render v. 26: "[His wrath] shatters the wicked, He slaps them in the place of (all) beholders." 28

Umbreit translates תחת רשעים by "Darum, das Frevel sie begingen." 29 However, the meaning "darum" for תחת is not attested in

21 Karl Budde, Das Buch Hiob übersetzt und erklärt (Göttingen: Vandenhoeck \& Ruprecht, 1896), 206.

22 Heinrich A. Hahn, Commentar ueber das Buch Hiob (Berlin: J. A. Wohlgemuth, 1850), 274.

23 Ferdinand Hitzig, Das Buch Hiob übersetzt und erklärt (Leipzig: C. F. Winter, 1874), 254. He renders v. 26a: "An die Platz der Verbrecher schmeist er sie."

24 Franz Delitzsch, Biblical Commentary on the Book of Job, vol. 2 (Edinburgh: T\&T Clark, 1869), 257.

25 Victor E. Reichert, Job (London: Soncino Press, 1960), 179.

26 Driver and Gray, Job 2, 260.

27 Budde, Hiob, 206.

28 Driver and Gray, Job 1, 300.

29 Friedrich W. C. Umbreit, Das Buch Hiob (Heidelberg: Mohr, 1824), 326. He means "for being wicked." 
558 Pinker, "Restoration of Job," OTE 29/3 (2016): 550-580

the Tanakh. In Schlottmann's opinion תחת רשעים"mit den Ruchlosen," literally "unter den Ruchlosen"; תחת has the same sense as in Isa 10:4. ${ }^{30}$ Pope suggests that the preposition תחת might mean here "among," as in 40:12. ${ }^{31}$ This sense for תחת is not attested in the Tanakh, and even Pope does not use it in v. 40:12. Gordis takes תח = "in recompense" (Gen 44:4; 1 Sam 25:21; 2 Sam 16:12; Ps 38:21; 109:4). ${ }^{32}$ Hakham has תַַח = "in the place of the wicked, the actual place" ( (במקום רשעים ,ממש "Arnheim has strangely "die Stellvertreter der Freveler" for אשר תחת instead of תחת רשעים; ently moving אשר from v. 27 to the beginning of v. 26. Beer connects the last word of v. 25 to the following verse but reads ידעכו. He says: "Vielleicht ist v. 26a so zu lesen (... ידעכו מתחתם רשעים): 'die Frevler sind von ihren platz gestossen.",35 Habel renders תחת מתח by "because,"36

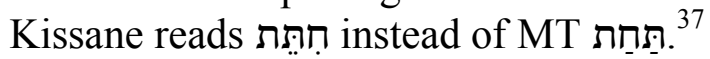

- "for their wickedness." The MT does not have anything that corresponds to "for" in the translation. This addition turns v. 26a into a statement of cause. The translation also revocalizes and emends MT

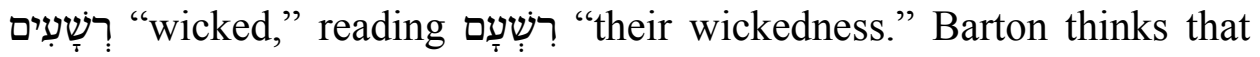
taking כרשעים = תחת רשעים is "hardly defensible." He opts for the read-

30 Konstantin Schlottmann, Das Buch Hiob (Berlin: Weigand and Grieben, 1851), 429.

31 Pope, Job, 259. Dahood observes that: "In the light of Aqhat: V:6f., ythb bap tǵr tḥt adrm dbgrn 'He sits at the edge of the gate, among the mighty men who are on the thrashing floor,' J. Greenfield has proposed that tahat, parallel to $\mathrm{b}$ in Isa 57:5b denotes 'among.' The recognition of this signification of tahat, also parallel to b, but in reverse order, leads to a clearer, though not entirely satisfactory understanding of the verse." Cf. Mitchell J. Dahood, "Northwest Semitic Philology and Job," in The Bible in Current Catholic Thought, Gruenthaner Memorial Volume, ed. John L. McKenzie (New York: Herder \& Herder, 1962), 71.

32 Robert Gordis, The Book of Job: Commentary, New Translation, and Special Notes (New York: Jewish Theological Seminary of America, 1978), 391.

33 Amos Hakham, ספר איוב (Jerusalem: Mosad HaRav Kook, 1981), 265. Cf. Exod $16: 29$.

34 Heymann Arnheim, Das Buch Job (Glogau: H. Prausnitz, 1836), 200. Arenheim finds a strong connection between v. 26 and v. 24. He says: "Sinn: Jene frevelten unter dem Deckmantel des Geheimnisses: darum ist auch ihre Strafe in Nacht gehüllt; diese ließen sich durch das Beispiel ihrer Vorgänger nicht abschrecken.”

35 Beer, Der Text, 219. Beer notes that Ken. 384 has תחתם.

36 Norman C. Habel, The Book of Job: A Commentary (Philadelphia: Westminster Press, 1985), 474.

37 Edward J. Kissane, The Book of Job (Dublin: Browne \& Nolan, 1939), 230. He inserts from v. 27a at the beginning of v. 26a reading על־כן חיתת רשעים "Therefore has he smitten the wicked." 
Pinker, "Restoration of Job," OTE 29/3 (2016): 550-580

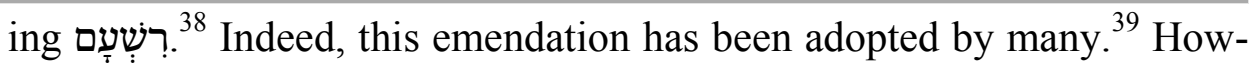
ever, Dillman argues that in the Tanakh רְשָׁעִים is always the plural of

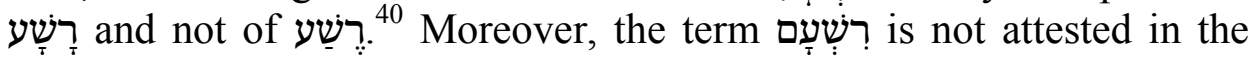
Tanakh, though possible. Duhm reads instead of v. 26a in the MT: "Sie warden zermalt unter Trümmern." "ִַּחת רְסִסים

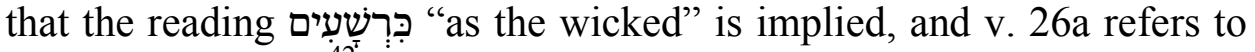
the כבירים (v. 24a).

- ספפָּקָ = "he strikes them." The verb "slap, clap" and by extension "chastise"; it does not indicate a forceful act. Gaab argued that:

etwas bedenklich und nicht erwiesen ist, dass ספק percutere über-

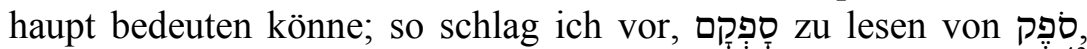
das sich nach dem Syrischen: evacuation, vacuitas geben läßt."

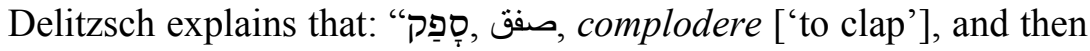
ictu resonante percutere ['to smack'], as the likewise cognate سفق signifies first to box the ear (as صفق =سفق), then so to strike that it smacks. $^{44}$

Hitzig says: "ספק, hier transitive (s. zu V. 37) wie Jer 48:26 aktiv, besagt: er schlägt d. h. schleudert sie hin, dass es schallt."45 Tur-Sinai maintains that the root ספק ,שפק has the primary meaning "to fill the

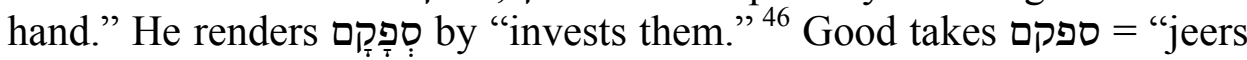
at them," but fails to explain how would we know when God jeers at someone. $^{47}$

38 George A. Barton, Commentary on the Book of Job (New York: Macmillan, 1911), 265.

39 Cf. George R. Noyes, The Book of Job (Boston: James Monroe, 1838), 65; Barton, Job, 265; Habel, Job, 474; Gordis, Job, 391; Clines, Job 21-37; and others.

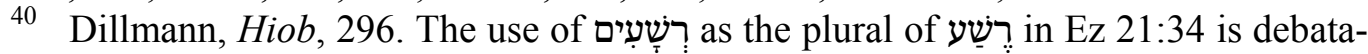
ble.

41 Bernhard Duhm, Das Buch Hiob (Leipzig: J.C.B Mohr, 1897), 166.

42 Hakham, 265.

43 Johann F. Gaab, Das Buch Hiob (Tübingen: J. G. Cotta'schen, 1809), 52.

44 Delitzsch, Job 2, 257.

45 Hitzig, Hiob, 254.

46 Naphtali H. Tur-Sinai, The Book of Job (Jerusalem: Kiryath Sepher, 1967), 483. He translates v. 26 "he invests those (others) instead of the wicked, in the place of the unclean." However, the wicked are not necessarily unclean.

47 Edwin M. Good, In Turns of Tempest: A Reading of Job with a Translation (Stanford: Stanford University, 1990), 144-145. 
- "where all can see." Budde finds v. 26b "ein wunderlich abschwächender Ausdruck für "vor aller Welt, vor Aller Augen.",48 Driver and Gray agree that "The phrase seems rather weak." says that תמקום has the same meaning (i.e., "like" or "as") as reads ראים instead of רשים, רשעים רמם רעים. in parallel with רשים. Ehrlich suggests that: "במקום רעים im Sinne von 'als gemeine Verbrecher' zu fassen."50 Good renders ראים by "those who see." He comments: "I think that the word is less casual than 'onlookers' may suggest." T1 Tur-Sinai avers that: 'ראים is not 'seeing ones,' but 'impure ones,' as ראו ראו'. ראי above, 33:21.,"52 Dhorme says: "we prefer to keep the present text and to restore to the hemistich normal proportions by placing the relative אשר, which overloads the beginning of v. 27 between במקום and משים 53

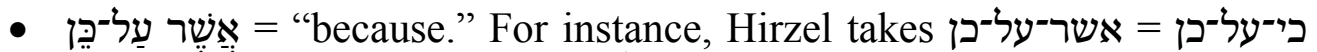

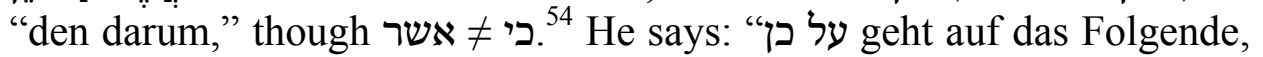
wie 20:2, und wird in להביא v. 28 wieder aufgenommen: darum, um gelangen zu Machen." 55 One wonders if the author could have expected the reader to make easily this connection. Hahn says:

Das אֶֶׁׁist nicht das Pronomen, bezüglich auf die hohen Sünder:

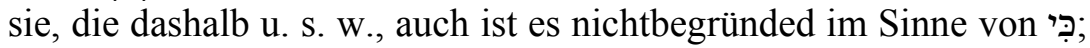

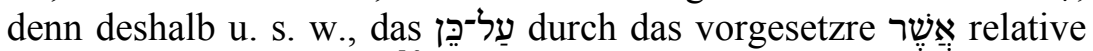
Bedeutung: darum, weil. ${ }^{56}$

The phrase does not occur anywhere else in the Tanakh, and is obviously awkward. ${ }^{57}$ One may wonder why the author used this phrase when he could have improved the meter by having כי instead. Hitzig notes that

(Gen 18:5, 19:8, Richt

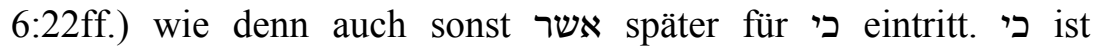

48 Budde, Hiob, 206. Budde is uncertain "ob man ihn [v. 26b] nicht in seiner unverhüllten Prosa zu belassen und mit v. 25 als Glosse zu streichen hat."

49 Driver and Gray, Job 2, 260.

50 Ehrlich, Randglossen 6, 316-317. He says: "vgl. Hos 2:1, wo תחת für steht, wenn auch in einem andern Sinne."

51 Good, Turns, 144.

52 Tur-Sinai, Job, 483.

53 Dhorme, Job, 522. He reads: במקום אשר ראים.

54 Robert D. Holmstedt, "The Relative Clause in Biblical Hebrew: A Linguistic Analysis" (Ph.D. diss., University of Wisconsin, 2002), 6-20, http://individual.utoronto.ca/holmstedt/HolmstedtDissertation.pdf.

55 Hirzel, Hiob, 205.

56 Hahn, Commentar, 274.

57 A somewhat similar expression, כי על־כן, occurs in Num 10:31, Ps 45:3. 
unwesentlich; in על־כן (Z. Ps 45:3) oder לכן (V. 25) findet Umkeruhng von Grund und Folge stat. ${ }^{58}$

Tur-Sinai suggests that the phrase is equivalent to על אשר, על כי, and the כן was added for emphasis. ${ }^{59}$ However, he does not explain how his assumption could have led to the MT.

Budde observes that:

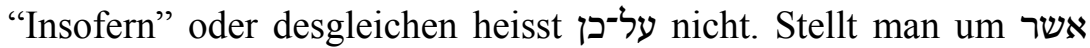

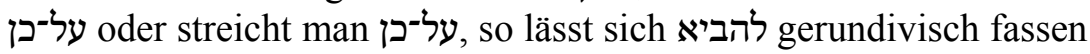
"indem sie bringen" und v. 27f. als Begründung der Strafe in v. $25 \mathrm{f}^{60}$

\section{Schlottmann observes:}

Manche nehmen das אשר על כן nach chaldäischer Weise als Versetzung für על כן אשר, aber letzteres kommt nicht vor und dagegen spricht auch shon dies, dass dadurch der schöne Zusammenhang von V. 27 und 28 zerrissen un V. 28 auf unerträgliche Weise isolirt würde. ${ }^{61}$

\section{Dillmann explains that}

die persönliche Fassung von אשר genügt (s. V. 19), und ist kein Grund, es (Hirzel, Delitzsch, Hitzig) = כי zu nehmen; על־כן weist auf das folgende (vgl. 20:2) und wird in ... להבי לביא erklärt. ${ }^{62}$

Indeed, Duhm takes על־כן being the original for which the variant אשר has been proposed and became part of the text. ${ }^{63}$

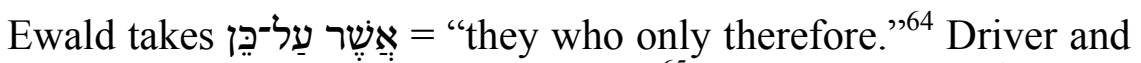
אשר על־כן Gray render this phrase by "forasmuch as." "that is why," which turns v. 27 into a rationale for being wicked and על

58 Hitzig, Hiob, 254.

59 Tur-Sinai, Job, 483.

60 Budde, Hiob, 206. Budde says: "Das על־כן kann als Erläuterung an den Rand geschrieben und eingedrungen sein."

61 Schlottmann, Hiob, 429.

62 Dillmann, Hiob, 296.

63 Duhm, Hiob, 166. Duhm considers v. 27 being a gloss, saying: “An diesen Satz [v. 26] schliest sich v. 28 eng an, und schon deswegen ist v. 27 eine Glosse."

64 Georg H. A. Ewald, Commentary on the Book of Job (London: Williams and Norgate, 1882), 338 .

65 Driver and Gray, Job 1, 300.

66 The wicked are jeered because they are wicked and are wicked because they are jeered. 
'so' zu streichen (Beer) statt das jetzingen 'die darum." "67 However, neither Beer nor Fohrer provide any justification for this emendation.

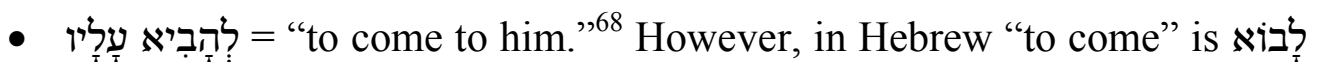

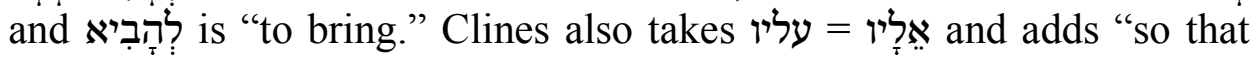
they caused" at the beginning of v. 28. A somewhat fuller translation of this phrase is provided by Driver and Gray: "that they may cause to come unto him."69 This translation preserves the reading עליו, but is too intrusive on the deity.

Dillmann suggests that עליו has here the sense "in his presence."70 Dahood says that: "this insight is confirmed by Ugaritic ' $l$ (also inscriptional Aramaic), which with certain verbs denotes 'in the presence of.", D1 Delitzsch renders עליו = "before him" (perhaps with the idea of urging forward). ${ }^{72}$ Similarly, Duhm renders the phrase: "Vor sich zu bringen."73 In Ewald's view vv. 27-28 convey the idea that

these infatuated potentates, who, when their fate is looked at from the point of view of this end [v. 26], seem to have departed from God and to have fallen into unrighteousness simply in order to bring the complaint of those who are unjustly tormented the more certainly before God's throne. ${ }^{74}$

This is a rather strange theological perspective.

על Driver and Gray observe that whether להביא כן or on the verb in 27 , the meaning is the same. The verse expresses the intention of the actions described in 27." 75 Dhorme says:

על has the sense of a gerund (31:30). The verb הביא, with before complement of person (Gen 18:19). The preposition is delib-

67 Georg Fohrer, Das Buch Hiob (KAT 16; Gütersloh: Gerd Mohn, 1963), 464.

68 So also translate Beer (Der Text, 219); Kissane (Job, 229); and others. Kennicott MS 125 and Rossi MS 349 have אליו.

69 Driver and Gray, Job 1, 300.

70 Dillmann, Hiob, 296. Dillmann renders: "vor ihn zu bringen," relying on 2 Sam $15: 4$.

71 Dahood, "Northwest," 69.

72 Delitzsch, Job 2, 258. Similarly, Schlottmann (Hiob, 429) renders by "Um vor ihn zu bringen."

73 Duhm, Hiob, 166. Duhm observes: "Der Satz [v. 26] führt die Rede auf ein Nebengelese; es handelt sich nicht darum zu erklären, warum gewisse Leute zermalmt werden, sondern darum, dass Gott die Schuldigen zu treffen weiss. Diese züchtigt er, wie v. 28 fortfährt."

74 Ewald, Job, 338.

75 Driver and Gray, Job 2, 261. 
erately chosen because what is in question is a prayer which rises to God. $^{76}$

Habel renders להביא by "he lets reach," which is unattested in the Tanakh." Rabinovitz and Abronin suggest that יביא = "they brought," as in Gen 42:25 להשיב means "they returned."78 Gordis says

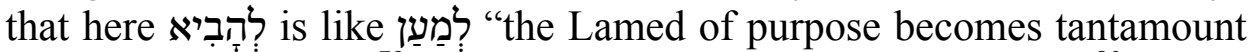

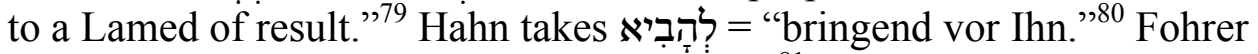
renders the phrase by "so daß sie brachten." 81 Barton considers vv. 28to be "An interpolation - a fragment of a poem on kings." 82 Hitzig takes the contrarian view, in which על, "upon," refers to the wicked (of v. 26); taking "in dem er über sie bringt.",83

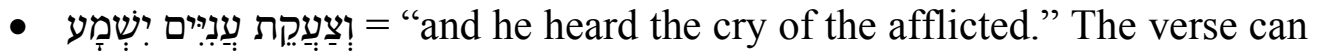
be seen as being structured in a manner similar to v. 33:17 and suggesting quick processing. Commentators usually keep ישמע in v. 27. However, the word reflects God's reaction as do ישתר and ישתר. It should logically belong to v. 28 .

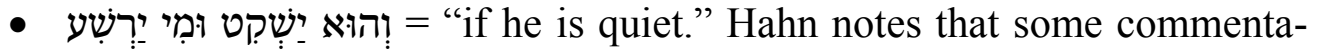
tors, relying on the Arabic سقط "to fall," gave the sense 'zu Boden stürzen.' However, in his opinion “Allein wir haben durhaus kein Recht abzugeben von der gesicherten Bedeutung des Wortes: Ruche haben." 84 The verb י-שְִׁיָט, deffectiva hip 'il imperfect of שקט, means "he quiets." In

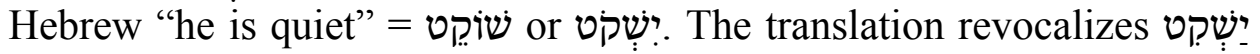
and supplements "if." It should be noted that the hip 'il of שקט could be

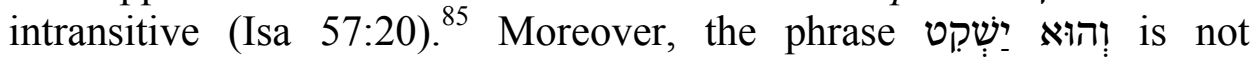

76 Dhorme, Job, 523.

77 Habel, Job, 474.

78 A. Z. Rabinovitz and A. Abronin, איוב (Jaffa: Shushni, 1916), 85.

79 BDB, 775b; Gordis, Job, 392.

80 Hahn, Hiob, 274.

81 Fohrer, Hiob, 463.

82 Barton, Job, 265.

83 Hitzig, Hiob, 254. Hitzig argues that common interpretations assume אליו = עליו relying on the identity of the suffixes in v. 27 and 28. He notes: "Aber sie lassen die Sache doch nicht selbstthätig (Ex 18:22) an Gott gelangen, bringen sie nicht an ihn;

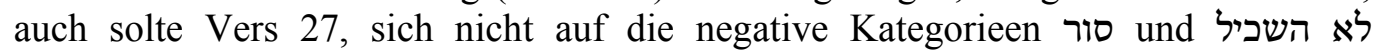
beschränken, in welchen Bedrückung der Armen nicht enhalten und nicht angedeutet ist. In eine Verbindung wie diese konnte kein Leser על im Sinne von אל verstehn."

84 Hahn, Hiob, 275. Cf. Umbreit, Hiob, 327.

85 For instance Budde (Hiob, 207) observes: "ישְקט als Hiph. kann zwar nach Jes 7:4, 57:20, Jer 49:23, Hi 37:17 'Ruhe halten' bedeuten; doch dürfte die Punktierung, zumal das von Gott nicht vorkommt, auf falscher causativer Auffassung beruhen. Lies ישקט ישישֶקט יש:." Schlottmann (Hiob, 430), for instance, prefers to consider here being intransitive. 
564 Pinker, "Restoration of Job," OTE 29/3 (2016): 550-580

conditional. Driver and Gray argue that "both lines [29a and 29b] are conditional sentences without conditional particles: for the rhetorical question as the apodosis." 86

Dillmann explains that:

השקיט ist nicht Ruche und Glück spenden Ps 94:13, sondern Ruche schaffen gegen die schreienden Gevaltthater der Mächtigen, vgl. Jes 14:7, Ps 76:9, wogegen Ruhe halten d.h. den Frevelern keine Hilfe geben einen V. 28 nicht ausgedrückten gedanken einmischt. ${ }^{87}$

Ehrlich notes that:

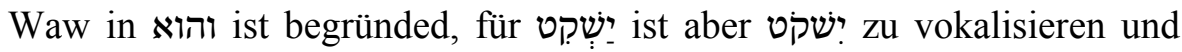

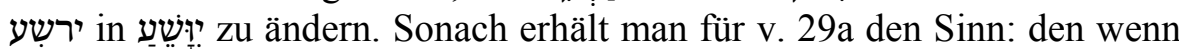
er sich untätig verhält, wer kann dann gerettet werden ${ }^{88}$

Dhorme rendered וְהוּא יַישְִקט by "if He rests." = "he gives content" (i.e. "freedom from care and discomfort"), which does not capture the sense of שקט in Hebrew and Arabic. ${ }^{90}$ The reading ישׁקיט has been adopted by many. ${ }^{91}$ Guillaume notes that:

One MS has yišqôt, and the meaning could then be 'if God by remaining quiet and not interfering, fails to condemn a man what right has anyone to do so?' Nevertheless it is tempting to regard the verb as a metathetical form of yaqšit (see Prov 22:21 for the noun and of Arabic qasata, 'he acted justly') and translate 'If he declares a man just, who can then condemn him? At any rate only thus can the latent antithesis be clearly brought out. ${ }^{92}$

However, the reader who is aware of the frame narrative would find such a perspective being contradictory.

Hitzig says: "ירְשׁעע Gegensatz; und unter Vergleichung von Jes

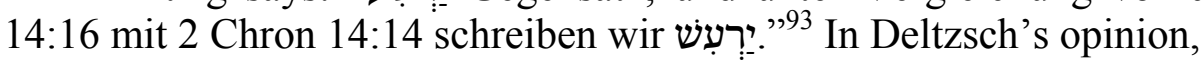

86 Driver and Gray, Job 2, 261.

87 Dillmann, Hiob, 296.

88 Ehrlich, Randglossen 6, 317.

89 Dhorme, Job, 523.

90 Good, Turns, 145.

91 Cf. Kennicott MS 235; Budde, Hiob, 207; Barton, Job, 266; Kissane, Job, 229. The hip 'il of שקט nowhere else in the Tanakh refers to God.

92 Alfred Guillaume, "Arabic Background of the Book of Job," in Promise and Fulfillment: FS for S. H. Hooke, ed. F. F. Bruce (Edinburgh: T \& T Clark, 1963), 122. 93 Hitzig, Hiob, 255. The cited source $2 \mathrm{Chr}$ 14:14 does not appear correct (1 Sam $14: 47 ?)$. 
The conjecture ירְִּש is is not required either here or 1 Sam 14:47 (where הרשיע signifies to punish the guilty); ירְשׁע is also not to be

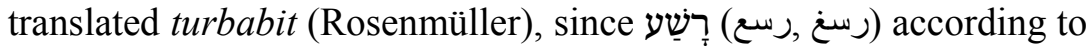
its primitive notion does not signify "to be restless, to rage," but "to be relaxed, hollow" (opposite of צה , עדק, to be hard, firm, tight).

Gordis says:

ירְשִׁׁ must mean "stir up, disturb." The meaning of the root probably derives from its etymology; cf. Arab. ras 'a "be loose (of limbs)."

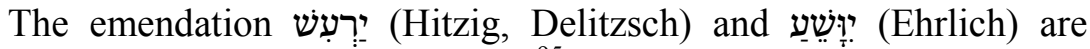
Schlimmverbesserungen (Budde). ${ }^{95}$

Rabinovitz and Abronin note that רשע is kindred to רתע in Aramaic, which means "to tremble, to be excited." better.

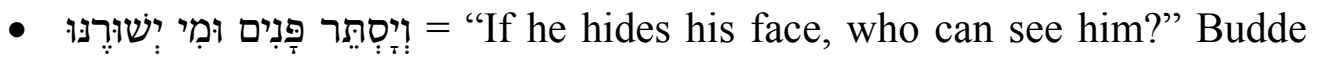
says:

d. h. trotziger Versuch der Selbsthülfe ändert nichts, es gilt zu warten, bis Gottes Gerichte reif sind. Obgleich das zulässig ist, wäre

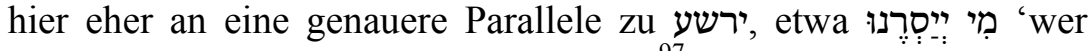
dürfte ihn tadeln?«(vgl. 40:1) zu denken. ${ }^{97}$

\section{Delitzsch observes:}

The Waw of ומי if one marks off the periods of the paratactic expression, is in both cases the Waw of conclusion after hypothetical antecedents, and verse $29 \mathrm{~b}$ refers to Job's impetuous challenging of God. $^{98}$

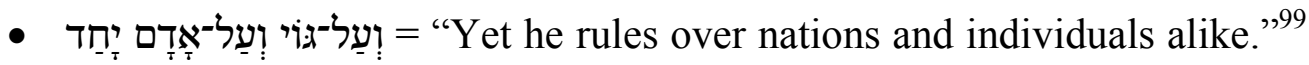
The MT does not have anything that corresponds to "yet he rules." Colon $29 \mathrm{c}$ is usually attached to the following verse. For instance, Ehrlich asserts that: "Das dritte Glied ist zum folgenden Verse zu ziehn, der für sich genommen keinen Sinn gibt."100 Gordis says that attaching

94 Delitzsch, Job 2, 258.

95 Gordis, Job, 392. Gordis finds in v. 29a an idea that is similar to that of Isaiah (Isa 57:20). The emendation יִרְעִש has also been adopted by Beer (Der Text, 219); Dhorme (Job, 543).

96 Rabinovitz and Abronin, 85. Cf. 1 Sam 14:47.

97 Budde, Hiob, 207.

98 Delitzsch, Job 2, 258.

99 Hakham (איוב, 265), suggests that is a parenthetic clause which states that despite vv. 29a-29b God is near every nation and man. He seems to be reading into the text a theological view that cannot be anchored in the MT.

100 Ehrlich, Randglossen 6, 317. 
566 Pinker, "Restoration of Job," OTE 29/3 (2016): 550-580

stich $\mathrm{c}$ to the next verse "improves the rhythm of both verses substantially." 101 Fohrer thinks that "Über dem Volk und über den Menschen insgesamte ist als erläuternde Glosse zu 'wahrnemen' zu streichen."102 Hirzel suggests that על = "gegen."103

Good takes אדם = "race," but most modern interpreters opt for "individual," in antithesis to גוי "104 For instance, Delitzsch explains:

God rules both over the mass and over individuals alike, יחד gives intensity to the equality thus correlatively $(e t-e t)$ expressed (Targum, Syriac); to refer it to אדם as generalizing (LXX, Jerome et super omnes homines), is forbidden by the antithesis of peoples and individuals. ${ }^{105}$

Habel keeps this colon in v. 29 and understands it as a detailing of who would not be able to see God. ${ }^{106}$

101 Gordis, Job, 392. He suggests that 'the double Vav means 'both ... and' as in Arabic wa ... wa" (BDB, 253a).

102 Fohrer, Hiob, 464. Fohrer renders v. 29b: "Wenn er sein Augensicht verbirgt wer nimt ihm wahr?" This is also Budde's position. Budde (Hiob, 207) says: "c gibt eine Erläuterung zu a und b, unmittelbar abhängig von ישקט und 'sei es nun über ein Volk, sei es über den [einzelnen] Menschen (hier auffallend für גבר ישת oder איש gleicherweise«, d. h. beide dürfen Gott nicht tadeln, wenn er einmal auf seine Hülfe warten lässt. Das ist freilich sehr prosaisch ausgedrückt und zudem nicht am Platze. Denn die Gerechtigkeit Gottes wird in c. 34 überhaupt nur an grossen Ereignissen, an Volksschicksalen, erwiesen, und v. 30 zeigt deutlich, dass es auch fernerhin dabei bleibt. Ein Interpolator oder Glossator hat es für nötig gehalten hervorzuheben, dass diese Ausführungen auch auf den Einzelnen, d. i. auf Hiob, Anwendung fänden, während der Verfasser dessen besonderen Fall absichtlich möglichst bei Seite geschoben hat und ihm selbst diesen Schluss zu ziehen überlässt. Streiche also c!"

${ }^{103}$ Hirzel, Hiob, 206. Cf. Aron Pinker, "Upon an Attack in Nahum 2:2," JHScr 4 (2002-2003), 1-4.

104 Good, Turns, 145. Good consistently translates אדם by "race" also in v. 30. Driver and Gray (Job 2, 262-263) note that "the singular אדם does at times refer not to the race, but to individuals of it, and may sometimes be idiomatically rendered in English by any one; see, e.g., Lev 1:2, 13:2. It is, however, a different matter for this properly collective term to express the idea of the individual in contrast to a collectivity such על is the original text, and, if so, whether it means towards a nation or towards an individual." Ehrlich, Randglossen 6, 317, says: "Das erste אדם מרד bezeichnet nicht einen einzelnen Menschen im gegensatz zu גוי, sondern hat ungefahr denselben Sinn wie dieses."

105 Deltzsch, Job 2, 259.

106 Habel, Job, 474. He reads: "If he hides his face, who can see him - Be it a nation or all humanity?" This translation does not correspond to the MT. 
Many emendations have been proposed for the word יחד. For instance, Duhm says: "Für יחד am Schluss von v. 29, an dessen Stelle

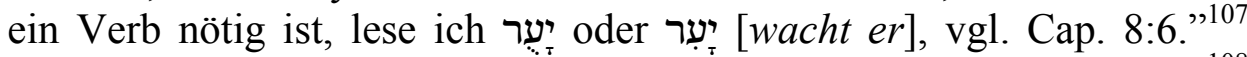

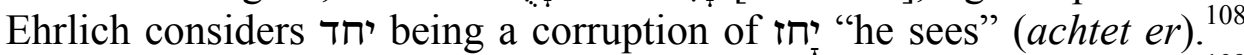
However, the ketib-qere apparatus does not attest to the $T / \tau$ confusion. ${ }^{109}$ Dahood explains that יחד is a dialectical form of "see." 110 Kissane

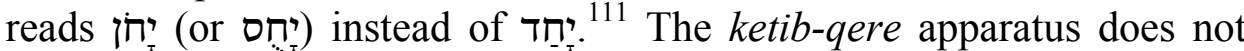
attest to $T / \uparrow$ or $T / D$ confusions.

- "so that the godless would not govern." MT does not have a word that corresponds to "so," and ממלך = "would not govern." Delitzsch takes מִהיוֹת = מִ and renders "in order that godless men may not rule" (e.g. 2 Kgs 23:33, Isa 25:2, מעם 48:2, מגוי 48:2, and the like). ${ }^{112}$ Hakham understands v. 30 as meaning "because ... rules them"

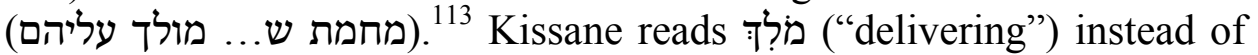

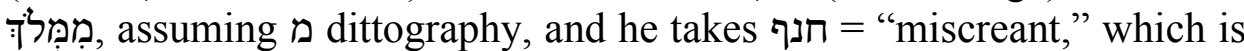
unattested in the Tanakh. ${ }^{114}$ Indeed, Gordis notes that interpretations of

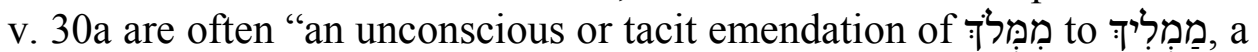
reading which virtually all moderns propose."115

The adjective חָָנָך means "profane, irreligious, godless," but not "wicked." Duhm says: "In v. 30 halte ich אָדָדם חָָנָּ für ein Interpretament zu dem folgenden Ausdruck: einer von den Fallstricken des Volkes, einer der das Volk umgarnt und für sich ausnützt."

${ }^{107}$ Duhm, Hiob, 167. The $\pi / y$ confusion is attested in 1 Sam 17:7 where we have וחק

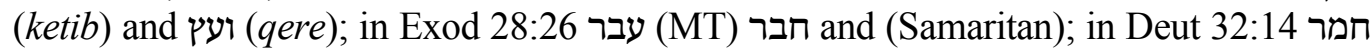

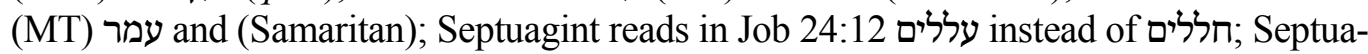
gint reads in Job שחר instead of שער (משר 34 ; there is an opinion that the Easterners

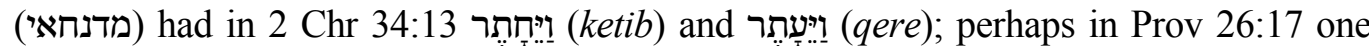

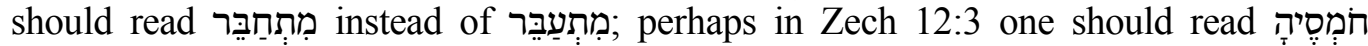

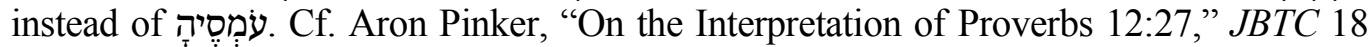
(2013): 1-8.

${ }^{108}$ Ehrlich, Randglossen 6, 317. Ehrlich is followed by Dhorme, Job, 524.

109 In Job 17:1, נזעכו is usually understood as נדעכו.

${ }^{110}$ Mitchell Dahood, "Ugaritic-Hebrew Lexicography," Bib 45 (1964): [393-412] 407-408.

111 Kissane, Job, 230.

${ }_{112}$ Delitzsch, Job 2, 259.

${ }^{113}$ Hakham (איוב, 266, note 25) considers v. being the continuation of v. 28.

${ }^{114}$ Kissane, Job, 230 and 229.

115 Gordis, Job, 392.

${ }^{116}$ Duhm, Hiob, 167. 
חנף by "condemned," which is unattested in the Tanakh. ${ }^{117}$ Dhorme moves חָָז to the beginning of v. $31 .{ }^{118}$

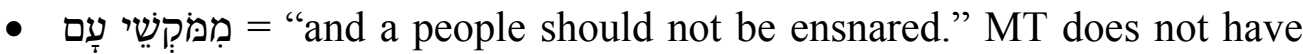
the conjunctive. The noun מקשי cannot correspond to the verb "ensnared," and the מקשי מקשי מs not equivalent to "not" but to "from" (מן) or "from being" (מִהְיוֹת) as in $1 \mathrm{Kgs} \mathrm{15:3,} \mathrm{Isa} \mathrm{7:8,} \mathrm{etcetera.}$ Good observes in despair:

Tur-Sinai's comment $(\mathrm{Job}, 484)$ that this is 'an unlikely expression even in Elihu's peculiar style' comforts me. The syntax of this and the two lines preceding escapes me, as does their relation to the couplet before them, though I think there is a connection. ${ }^{119}$

Gordis renders v. 30b: "because of the snares set by the people"; i.e., because of the offenses committed by them. ${ }^{120}$ Kissane reads ("affliction") instead of MT עָָם, apparently assuming the ligature $\square=$ ני. ${ }^{121}$ Hakham assumes that ממלך מקשי = ממקשם and

\section{Observations}

The preceding analysis leads the following observations:

(i) Exegetes had difficulty to define clearly what is the point that Elihu is trying to make in vv. 26-30? For instance, Kissane thinks that:

In this strophe, Elihu considers the great difficulty which can be raised against the doctrine of God's justice: Why does He sometimes allow the sinner to go unpunished? ${ }^{123}$

117 Habel, Job, 474.

118 Dhorme, Job, 524.

119 Good, Turns, 144. Cf. Tur-Sinai, Job, 484. Tur-Sinai, Job, 484, suggests the read-

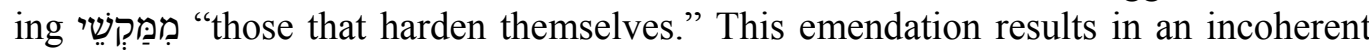
sense for v. 30; "That the unbeliever reign not, those that harden themselves among the people."

120 Gordis, Job, 393. Gordis says: "Verse 29 has indicated that God brings disaster upon men when He so chooses. In our view, v. 30 adds that God permits evildoers to hold sway in order to punish men and nations who have themselves been guilty of seeking to snare the innocent." It is difficult to find in this view any relevance to the Jobian problem.

${ }^{121}$ Kissane, Job, 230.

122 Hakham, 266. Cf. Exod 10:7.

${ }^{123}$ Kissane, Job, 234. Kissane (Job, 234) sees vv. 27-29b as presenting human concern at God's non-intervention in cases of obvious injustice. In his view vv. 29c-30 give Elihu's answer; "unfortunately, textual corruption has obscured the meaning." Kissane $(J o b, 229)$ restores the text to mean: "With a nation, or with a man he is com- 
However, Elihu gives no answer to this question. In Good's view Elihu goes on in these verses with describing God's opposition to the wicked. He 'jeers' (ספקם) at them (v. 26), turning those people away from him (v. 27). Simultaneously,

Elihu argues that Job was wrong about the deity's positive actions toward humans. Those who turn away from him fail 'to bring to him the outcry of the poor,' but he hears it nevertheless (v. 28). ... But his language becomes garbled and his thought unclear in verses 29$32 .^{124}$

Good's perspective on vv. 26-30 is hardly a coherent thematic framework for the unit. Similarly, Habel presents a logically confusing perspective by saying:

For Elihu, God's punitive action is not only righteous but executed "in 'a public place." ... The spectacle of Job's suffering on the ash heap is evidence of just such indictments by God. Those who turn from the ways of the divine wisdom produce social oppression and moral evil in the community. The 'cry of the poor' reaching heaven testifies to the cruelty caused by such corruption in society. ... By heeding their pleas for relief, God, as a just ruler, rescues them and thereby 'silences' them and any gainsayers. ... If, however, he hides his face in displeasure because of public evil, the absence of his favor will be evidence of his anger. ... The text of v. 30 remains obscure. $^{125}$

(ii) Exegetes had difficulty to identify the contextual connection of vv. 2630 to the preceding and following text.

(iii) Verse 28 seems to be contradictory, in suggesting that God needs the cry of the poor to be brought to him, yet he anyway hears it. Is it possible that ישמע is misplaced?

(iv) Is it possible that the order of the verses is incorrect, and v. 30 is the continuation of v. 28 ?

(v) Exegetes struggled reveal the logical connection between vv. 29 and 30 ? Dillmann observes:

Nämlich הסתיר פנים uönnen nicht die scheinbare Unthätigkeit Gottes beim hilfsgeschrei der Leidenden, als Gegensatz

passionate, Delivering a miscreant from the snares of affliction." This would be injustice, not compassion.

124 Good, Turns, 328.

125 Habel, Job, 485. Habel $(J o b, 476)$ says that v. 30: "seems to be corrupt and missing at least one verb." 
zu der vorher beschriebenen richtenden Thätigkeit besagen, weil in diesem Fall zwar die beiden Fragsätze einem guten, aber V. 30 keinen annehmbaren Sinn gäbe, sondern es muss vom Einschreiten Gottes zu dem V. 30 angegebenen Zweck die rede sein. ${ }^{126}$

Since the Book of Job deals with the fate of individuals alone, can it include such verses as 28-30? Barton notes:

Probably the interpolation [vv. 28-33] was introduced at some time of national oppression. It is particularly inept to the context here, where it comes between Elihu's description of the way that God destroys the powerful, and his conclusion that wise men must consider Job a sinner. ${ }^{127}$

Clearly something is wrong with the MT of vv. 26-30. One would be hard pressed to confidently state the meaning of vv. 26-30, or even conjure the image that these verses suggest, within the framework of the MT.

\section{PROPOSED SOLUTION}

Commentators usually agree that vv. 29-33 in MT are corrupt, few note the textual disorder of vv. 26-28. The solutions that are proposed for the difficulties in vv. 26-30 capitalize on some text-critical observations that have been frequently noted in ancient Hebrew manuscripts. The commonness of these observations makes it impossible to consider the textual disorders being intentional; the author's artistic means for conveying Elihu's excitement. This effort aims to restore a coherent thematic flow to the sub-unit that provides answers to the questions which were identified in the preceding section.

Verses 26-30 would be now discussed seriatim.

\section{$1 \quad$ Verse 26}

The difficulties associated with this verse stem from the words רשעים and תחת In the solution presented here, the focus is on whether the inconvenient תחת is authentic and whether רשעים was in the original text. Our approach to the restoration of v. 26 capitalizes on the similarities between our verse and v. 20a.

Beer aptly noted: “'Er geisselt sie wie (תחת) Freveler' würde in sich schliessen, dass die also Behandelten keine Frevler sind-das widerspricht V. 24." "28 While Fohrer does not find v. 26 inexplicable he still finds: "Wörtlich 'an Stelle von Frevlern ... an der Stätte der Sehenden (=Zuschauer).' Doch ist der text vielleicht verderbt." 129 At least these sentiments suggest that תחת is

126 Dillmann, Hiob, 296.

127 Barton, Job, 266.

128 Beer, Der Text, 219.

129 Fohrer, Hiob, 464. 
suspicious. One also notes the structural and thematic similarity between v. 26

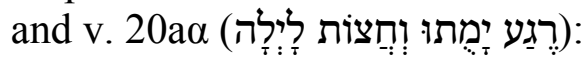

(i) both verses head the respective units vv. 20-25 and vv. 26-30;

(ii) $20 \mathrm{a} \alpha$ is a 2:2 verse and v. 26 is 'almost' (sans רשעים) 2:2;

(iii) in v. 20a $\alpha$ the referent is delayed, and in v. 26 the referent 'might' have been originally delayed, if רשעים is assumed to be a scribal gloss;

(iv) both verses deal with the demise of the powerful and inability to hide;

(v) ימתו in v. 26 parallels $20 \mathrm{a} \alpha$ and correspondingly are ספקום in anti-parallel. ${ }^{130}$

This remarkable similarity between v. 26 and v. $20 \mathrm{a} \alpha$ suggests that should be emended to have like רגע a sense of short duration. Such a sense is afforded by the reading תחת instead of תחת.

אחת could mean "once, just once, only" (2 Kgs 6:10, Ps 62:12, 89:36, Prov 28:18, Judg 16:28), thus conveying a small number requiring little time. Is it possible that a $\Omega / \boldsymbol{N}$ confusion occurred? While such confusion is orthographically unlikely in the square script, it is possible in a mixed Hebrew paleo script and square script. More than a century ago, Perles called attention to the similarity between $\boldsymbol{N}$ in Hebrew square script and $\Omega$ in the paleo script, and demonstrated its utility for resolving the difficulties in Ps 22:17. He says,

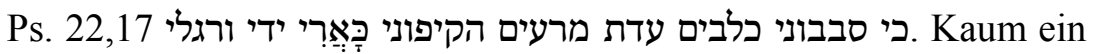
Wort in den Psalmen hat zu so vielen, zum Teil sonderbarn Erklä-

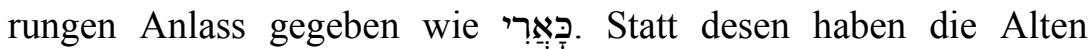
(Verss., מדרש תהלים, Massora, s. Grätz z. St.) ein verbum כארו gelessen, das zwar ebensowenig verständlich wie die Masoretische La. ist, aber dem Richtigen näher ist. Der Parallelismus mit Vers 13 סבבוני פרים רבים אבירי בשן כִּתִּרוּנִי

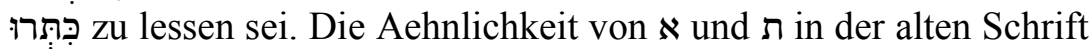
hat diesen Fehler herbeigeführt. ${ }^{131}$

Though Perles does not suggest other instances of the $\mathbf{k} / \Omega$ confusion, the case discussed by him is not likely unique. For instance, both early and modern

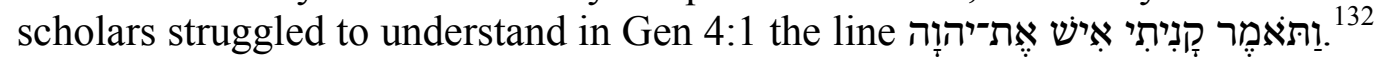

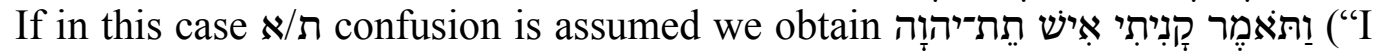
acquired a men to give God"). This interpretation, suggesting human sacrifice,

130 The similarity between וחצות לילה and particularly noticeable in the Septuagint's interpretation of v. 26.

${ }^{131}$ Felix Perles, Analekten zur Textkritik des Alten testaments (München: Theodor Ackermann, 1895), 50.

132 Naphtali H. Tur-Sinai, כרך הספר (Jerusalem: Mosad Bialik, 1960), 410. 
gives an intriguing twist to Cain's actions, which are rather puzzling in the MT.

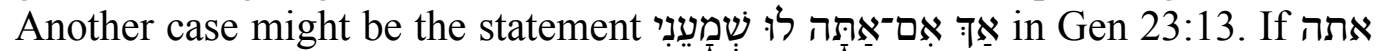

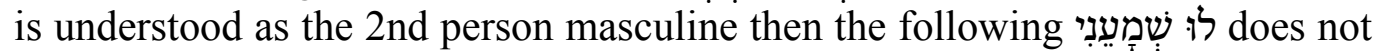
connect logically with it. However, using the

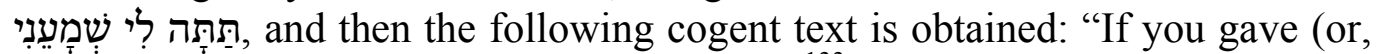
you are ready to give) it to me, then hear me." confusion might have occurred could be:

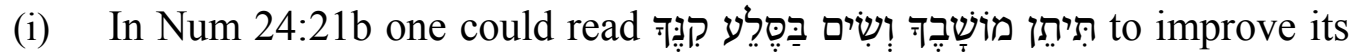
sense and inner parallelism.

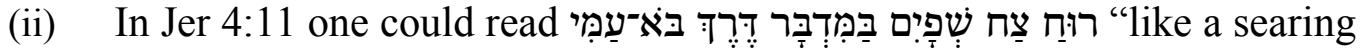
wind from the heights of the desert coming to my people" instead of MT

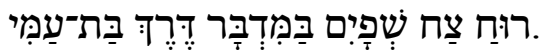

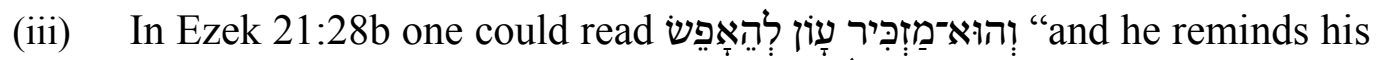

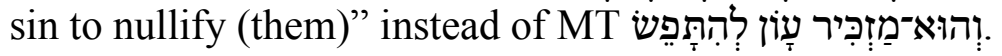

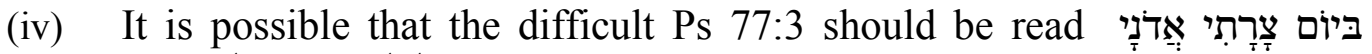

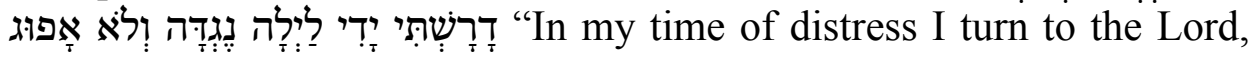
my hands [even] at night are in front of Him, I do not rest," assuming the $\mathrm{N} / \Omega$ confusion. ${ }^{134}$

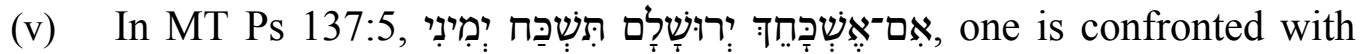
the impossible notion that the hand has a memory, and what it will forget is not clear. ${ }^{135}$ A more logical reading would be "Forgetting Jerusalem would be like forgetting my right hand"; that is, it is impossible.

The preceding instances of possible $\mathrm{N} / \mathrm{\Omega}$ confusion demonstrate that it is likely and might be more frequent than generally recognized. Whether this conאusion could have played a role in writing תחת instead of the original depends on when the Book of Job was written. The interval of time proposed by modern scholars extends from 11 th century BCE to the 3rd century BCE. There are no historical allusions in the book and its language does not allow an unambiguous dating. If the upper time limit is adopted, then it is possible that the book was written when the square script started to come in. At first the two script styles coexisted; the new script slowly replacing the paleo-script. The oldest inscription in the square script is that of Arak-el-Amir (Jordan), which dates from about $180 \mathrm{BCE}$. Though it contains only five letters it is a good

133 The form תָת occurs in 2 Sam 22:41.

134 Tur-Sinai, כרך הספר, 430. Cf. Ps 116:14, 18.

135 Usually Ps 137:5 is rendered: "If I forget Jerusalem, let my hand wither." Cf. TurSinai, כרך הספר, 122. 
example for the coexistence of the two styles even at some later time. ${ }^{136}$ Jewish papyri (Cowley papyri) discovered in Assuan (Egypt) indicate that intermediate forms, between the paleo-script and the square script, might have been used in the long transition to the square script. ${ }^{137}$ This would imply that the $\mathrm{\kappa} / \mathrm{\Omega}$ confusion could have been made even in the original manuscript. If the book was written anytime within the dating interval, it is possible that the transmitted manuscript is a copy that was transcribed at the time when both styles of script coexisted.

Clearly, the $\kappa / ת$ confusion could have been a factor in writing תחת instead of the original אחת during the period in which the two scripts coexisted. It is possible that a copyist, coming across אחת (written in the square script), thought that the first letter looks more like the paleo-script letter $\Omega$. It is notable that in v. 33:14 Elihu uses אחת perhaps to argue that God reveals himself "only in one" way to humans. Moreover, the reading אחת makes eminent sense. The

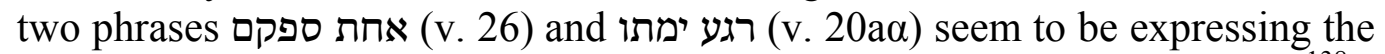
same idea. Thus, v. 26 in MT is unbalanced, as most commentators noticed. ${ }^{138}$

Verse 26 becomes balanced if it is recognized that רשעים could be an interloping word. It is easy to imagine how this word made it into the text. Conceivably, a scribe felt that in v. 26a a reader would be at loss about who the referent is. He helpfully wrote the word רשעים between the two words (in the space between two lines). Subsequently, as was often the case, a copyist assumed that this gloss is actually a textual correction and included it in the text. If it is assumed that in v. 26a רשעים is a later insertion, intended to clarify

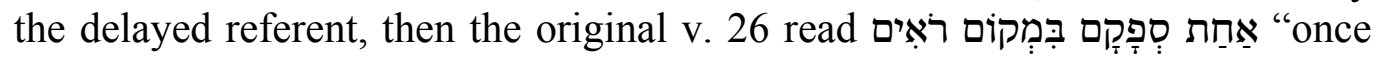
he strikes them in the place of (those) seeing."

\section{$2 \quad$ Verse 27}

Commentators have been baffled by the phrase אשר על־כן, which occurs only here. Kissane observes that:

In the beginning of the verse we have the impossible combination of the relative particle followed by "therefore." One or the other is superfluous. Dhorme transfers the relative particle to 26; on the contrary, it is the particle "therefore" that is to be transferred. The relative particle is used here to introduce a hypothetical case as in Lev. 4:22; Deut. 11:27; Jos. 4:21. The verse recalls 21:13-14: "They

136 Samuel R. Driver, Notes on the Hebrew Text of the Books of Samuel (Oxford: Clarendon, 1890), xxii.

137 Archibald H. Sayce and Arthur E. Cowley, Aramaic Papyri Discovered at Assuan (London: A. Moring, 1906), Papyrus 5.

${ }_{138}$ Dhorme, Job, 522. Dhorme notes: "There is a lack of balance between the two hemistichs. Various attempts have been made to connect with the 2nd hemistich and to extend the first." 
say to God: Depart from us! And we desire not the knowledge of your ways." 139

These are not the only possibilities for resolving the awkwardness of אשר על־כן. It is obvious that v. 27 identifies the referent for v. 26, as in v. 20, יגעשו עם ויעברו ויסירו אביר לא ביד, does for the preceding line. Thus the relative particle עשר must be moved. ${ }^{140}$ This approach leads to the coherent 3-beat colon אשר סרו מאחריו "that turned aside from following Him," and makes v. 27 into a 3:3 rhythm verse.

Verse 21 is in essence a poetically expanded כל דרכי וצעדי איש יראה, which shares with v. $27 b$ the words דרך, כל כיראה = ישכיל. The two verses seem to be juxtaposing the relationships of God vs. man and man vs. God; God being meticulous in observing and understanding human behavior, while man being remiss in his understanding of God's ways. Ehrlich felt that: "Statt וכל למכל hat man וְ וֵַל zu lesen. השכיל אל ל ist dasselbe wie השיל und heist, Rücksicht nehmen auf, berücksichtigen; sieh zu Prov 21:2 und vgl. Ps 41:2."141 Perhaps, understanding וְכָ as "and comprehend, assess" (Isa 40:12) would better fit the context. If these considerations are incorporated in v. 27 it would read:

That turned aside from Him

And have not wised up to comprehend His way

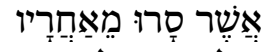

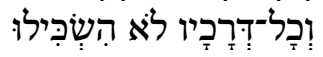

The delayed referent (for v. 26) are those that turned aside from God and did not make an effort to comprehend God's ways. A pious scribe would consider such individuals being wicked (רשעים) and engaged in exploitation of the poor.

\section{$3 \quad$ Verse 28}

The phrase על־כן "therefore," from the MT v. 27, belongs to the beginning of v. 28. This scribal error might have occurred because of the prevalent practice to correct errors of omission by writing the omitted word or phrase in the space between the lines. Verse 28 expands v. 27 by providing the consequences of the acts that it describes. The logic of vv. 26-28 is this: God publicly punishes (v. 26) those who abandoned God's morality (v. 27) and are bringing to Him the anguish of the exploited (v. 28). This chain of logic is then followed by other possible reactions that God might have (vv. 29-30).

139 Kissane, Job, 234. It is doubtful that the religiously rebellious tenor suggested by Kissane is realistic for the setting of the book and its time.

${ }^{140}$ Ehrlich, Randglossen 6, 317. Ehrlich says: "אשר bezieht sich auf das im Vorhergehenden beschriebene Verfahren Gottes gegen die frevelnden Herrscher und ist Subjekt des Satzes, während das darauf Folgende das Prädikat bildet."

${ }^{141}$ Ehrlich, Randglossen 6, 317. The כ ב confusion is not attested in the Ketib-Qere apparatus, and the two letters are not orthographically similar in the paleo-script or square-script. 
Driver and Gray note that "Dillmann supposes על כל to point on to להביא , who therefore have turned aside from after him, ... in order to bring." "142 This would assume knowledge of intent, which is speculative and unnecessary. It is possible to understand להביא = "to bring (repeatedly), bringing" and by extension "supplying." One would naturally expect that the anguish of the poor would rise by itself to heaven and would not require any visible (or metaphoric) transfer by the wicked.

The singular עליו and context would make God as the most likely referent in v. 28. However, this would require reading על אליו instead of MT (cf. Gen 18:21). It is notable that the עלא confusion is well-attested in the KetibQere apparatus and the many $\nu^{\prime} \mathrm{s}$ in this and following verse may have predisposed the scribe to writing an $y .{ }^{143}$

It seems logical to attach ישמע to the next verse, since v. 28 is focused on the anguish of the poor and ישמע describes God's reaction, as do the verbs in v. 29a. Also, without ישמע a 3:3 verse is obtained, that reads:

$$
\text { על־כן להביא אליו עקת־דל וצעקת עניים }
$$

Therefore supplying to Him the cry of the poor and the cry of the afflicted.

\section{$4 \quad$ Verse 29}

Budde characterized v. 29 and the verses that follow being:

Die dunkelste Stelle des Capitels, die ganz zu entwirren wohl nie gelingen wird. Den sichersten Faden bietet v. 29. Die ersten beiden Glieder bilden je einen Vorder- und Nachsatz, der erstere setzt ein Tun oder Verhalten Gottes, der letztere spricht dem Menschen für diesen Fall Recht oder Möglichkeit des Tadels oder des Ein greifens ab. Da nun Gott durchgängig als Hort der Gerechtigkeit dargestellt ist, gegen dessen Tun Einspruch zu erheben niemandem einfallen wird, so kann das hier gesetzte göttliche Tun nicht mit dem bisherigen (von v. 18 an) gleichartig sein, sondern muss im Gegensatz dazu stehn.

More recently, Gordis observed:

These vv. are justly described by Driver-Gray (vol, 1, pp. 301ff.) as being on the whole unintelligible or at least ambiguous. The passage has probably suffered textual damage which is unfortunately not repairable today. LXX omits the vv. ${ }^{144}$

142 Driver and Gray, Job 2, 260.

143 BDB, 4la, note that: "There is a tendency in Hebrew, especially manifest in Samuel, Kings, Jeremiah, Ezekiel, to use אֶֶ in the sense of

${ }^{144}$ Gordis, Job, 392. 
Gordis' assessment is perhaps too gloomy. Most commentators rightly attach v. $29 \mathrm{~b}$ to the beginning of v. 30. The restored v. 29 becomes then

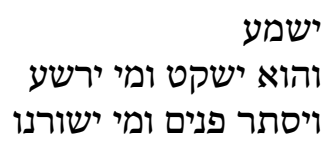

a 4:4 verse (indicating a conclusion). It should be understood as if the word ישמע precedes each colon:

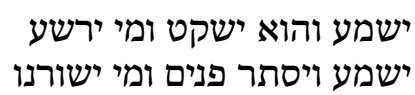

In addition to God's public (obvious) punishment of the wicked, it is also possible that God might seem apathetic (Hab 1:2-3), יישְׁקטט. He might hold back His benevolence, or metaphorically 'cover his face' not to see (Hab 2:13), יִסְתתר פָּנִים . In each case, as a sovereign deity He cannot be compelled to act and we cannot impose on Him our predilections.

\section{$5 \quad$ Verse 30}

In v. 29b the prefixing in ועל ו וְעַל , should be understood as or if; "or if upon." Ewald correctly sensed that vv. 29-30 express God's anger and his punitive reaction. However, his understanding of v. 28 reads into it more than it contains. He says that in Elihu's view: "He then indeed, takes rest, i.e. giving no more help (Ps 83:2, Zech 1:12-13) and turning his face away, coming with punishment both upon a nation and upon all persons of the earth."146

It seems more logical and useful to connect v. 29b with v. 30 and read יחד instead of The likelihood of a רדר רד confusion is well-attested in the ketib-qere apparatus and the Tanakh. ${ }^{147}$ י. . which occurs many times in the Tanakh, is the qal imperfect of חרה "burn of anger." It provides a verb for v. $29 \mathrm{~b}$ and allows anchoring in text typical interpretations of v. 29c such as "Ueber Volk und über Mensch zusammmen, über ganze Völker vie über

\footnotetext{
${ }^{145} \mathrm{BDB}, 252 \mathrm{~b}$

146 Ewald, Job, 338. There is nothing in MT that corresponds to "coming with punishment"; v. 29b has no verbs.

${ }_{147}$ One finds in the Ketib-Qere apparatus this confusion in: 2 Sam 13:37 עמיחור (K) but

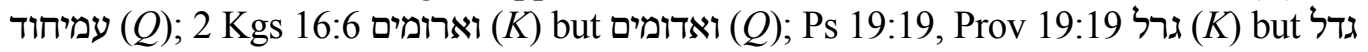

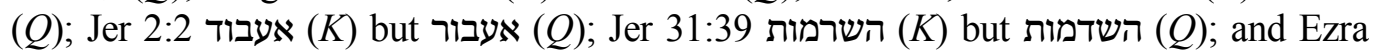

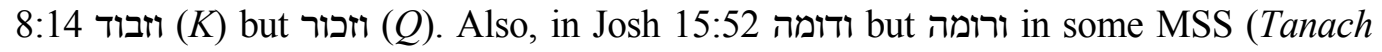
Koren, 11 end); 2 Sam 8 (many), 1 Chr 18 (many) הדרעזר - הדדעזר in some MSS (Tanach Koren, 12 end); in Hab 3:12 - Septuagint reads "you will bring low"

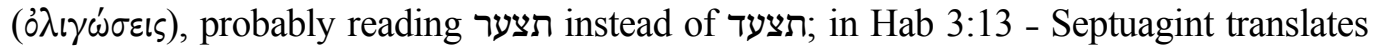

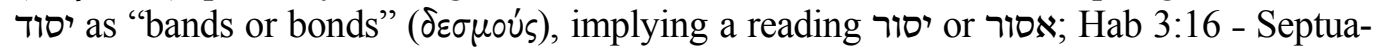
gint translates יגודנו as "of my sojourning” (יגורנו).
} 
Einzelne verhängt Er in zorne vernichtende Strafgerechte." ${ }^{148}$ Verses $29 \mathrm{~b}$ and 30 have been understood as depicting God being protective (Peshitta, Ehrlich, Kissane, Clines) or punitive (Septuagint, Vulgate, Hirzel, Hahn, Ewald, Gordis). Reading יחי יחד instead of sets us obviously on a punitive interpretation of v. 30 .

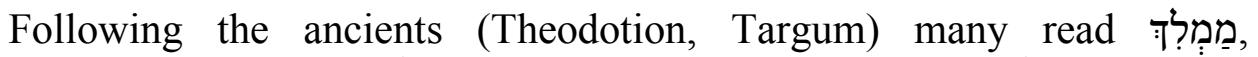

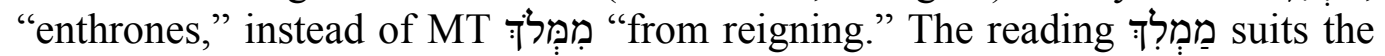
punitive interpretation that has been adopted in this solution; i.e., Elihu suggests that the enthronement of a חָזָר, "profane, irreligious, hypocrite" is a divine punishment. However, the phrase אדם חנף is problematic, since it never occurs elsewhere in the Tanakh. It seems likely that a scribe by mistake copied the word אדם from the nearby v. 29b and this word should be deleted.

Dillmann rightly says: "Die Lesart מַמְלִּ (Theodotion, Targum) erlaubt keine richtige Erklärung von ממקשי." 149 This difficulty can be resolved by noting that a simple and frequent error of metathesis occurred. One should read is a collective term for "thistles, nettles." קמוש word occurs only twice in the Tanakh (Isa 34:13, Hos 9:6); it is not surprising that a scribe confused it with the more frequent מוקש (21 times). The phrase מִקְּמֹטֵי עַם probably referred to the useless but potentially harmful

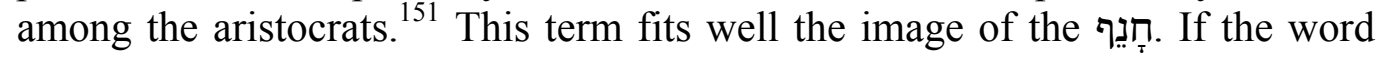

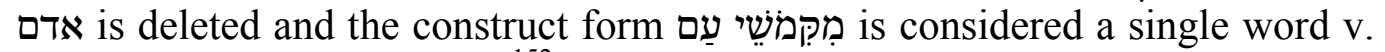
$29 b+30{\text { becomes a } 3: 3 \text { verse. }^{152}}$

Verse $29 b+30$ can be now restored as follows

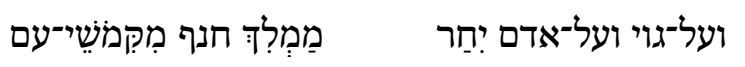

Or if upon a nation and man he angers,

he enthrones a hypocrite from the 'thistles' of the elite.

Though the verse does not appear to relate to Job's specific problem, it serves well to buttress Elihu's general argument that God is righteous and metes out punishment to nations and races as he does to individuals (vv. 26-28)

148 Hahn, Hiob, 275.

149 Dillman, Hiob, 297.

150 Jehuda Feliks, Plant World of the Bible (in Hebrew) (Massada: Ramat Gan, 1968), 211. Feliks describes the קמוש as a plant that wildly spreads in areas that became uninhabited. Classical Jewish commentators (Ibn Ganah, Rashi, Radak) the קמוש as Urtica.

151 Cf. Judg 9:9-15, where a bad king is likened to a bramble (אטד), and 2 Kgs 14:910 where an insignificant king is compared to a brier (חוח).

152 Budde, Hiob, 207. Budde says: "Die Kürze des Gliedes ist ... störend: bei unserer Auffassung wäre ein משֶׁל vor b möglich. Ferner könnte man so auch 29 c zu v. 30 ziehen; doch erweckt der Satz auch in dieser Verbindung nicht mehr Zutrauen." However, Budde's emendation is entirely arbitrary. 
even if He may seem as being apathetic and removed (v. 29a). As would be noted in the concluding section, the sensitized Job could have detected in Elihu's general statements many personal implications.

\section{CONCLUSION}

Relatively few minor text-critical emendations result in the following simple and coherent text:

Once he strikes them in the place of (those) seeing.

[Those] that turned aside from Him,

And have not wised up to comprehend His ways.

Therefore supplying to Him,

the cry of the poor and the cry of the afflicted.

He listens,

And if he keeps quiet, who can condemn him?

And if he hides his face, who can see him?

Or if upon a nation and man he angers,

he enthrones a hypocrite from the 'thistles' of the elite.

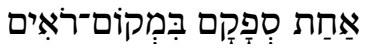

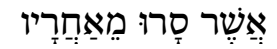

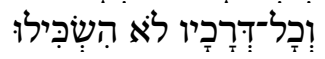

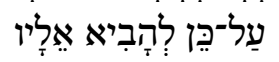

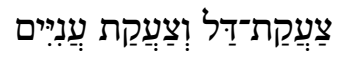

$$
\begin{aligned}
& \text { יִשְׁמַעע }
\end{aligned}
$$

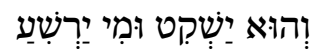

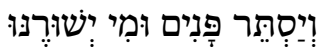

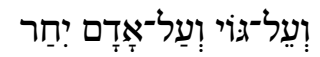

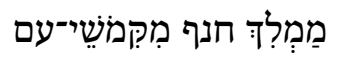

Orthographically, the restored Urtext does minimal violence to the consonantal text, while securing an unforced sense and a typical 3:3 rhythmic structure.

The unit is focused on potentates that have lost their moral compass and God's reaction to their deeds. In this sense, the unit consisting of vv. 26-30 fits contextually the larger unit consisting of vv. 16-30, which deals with God's righteous management of nations and people. Job's personal problem is addressed only indirectly. Job could deduce relevant references to his situation from the following statements made by Elihu:

(i) Job's visible punishments indicate that he sinned (v. 26).

(ii) Job is ignorant of God's ways and abandoned moral behavior (v. 27).

(iii) Job has caused anguish to the destitute, which reached heaven (v. 28).

(iv) If Job has a case then it has been heard, though there may be a delay in God's reaction (v. 29a).

(v) Job cannot compel God to confront him (v. 29a).

(vi) God works in mysterious ways (vv. 29b-30).

Elihu's message is hard hitting, but is not devoid of hope. In the verses that follow Elihu spells out what he expected Job to do. 


\section{BIBLIOGRAPHY}

Arnheim, Heymann. Das Buch Job. Glogau: H. Prausnitz, 1836.

Andersen, Francis I. Job: An Introduction and Commentary. London: Inter-Varsity Press, 1976.

Barton, George A. Commentary on the Book of Job. New York: Macmillan, 1911.

Beer, Georg. Der Text des Buches Hiob. Marburg: N. G. Elwert, 1897.

Brenton, Lancelot C. L. The Septuagint with Apocrypha: Greek and English. London: Samuel Bragster and Son, 1851. Repr. Peabody: Hendrickson, 1987.

Brown, Francis, Samuel R. Driver and Charles A. Briggs. The Brown-Driver-Briggs Hebrew and English Lexicon. Oxford: Oxford University Press, 1906. Repr. Peabody: Hendrickson, 2001.

Budde, Karl. Das Buch Hiob übersetzt und erklärt. Göttingen: Vandenhoeck \& Ruprecht, 1896.

Caspari, Carl P. Das Buch Hiob $(1,1$ - 38,16) in Hieronymos's Uebersetzüng aus der alexandrinischen Version nach einer St. Gallener Handschrift. London: Luzac, 1893.

Clines, David J. A. Job 21-37. Word Biblical Commentary 18A. Dallas: Word Books, 2006.

Delitzsch, Franz. Biblical Commentary on the Book of Job. Volume 2. Edinburgh: T and T Clark, 1869.

Dahood, Mitchell J. "Northwest Semitic Philology and Job." Pages 55-74 in The Bible in Current Catholic Thought, Gruenthaner Memorial Volume. Edited by John L. McKenzie. New York: Herder \& Herder, 1962.

."Ugaritic-Hebrew Lexicography.” Biblica 45 (1964): 393-412.

Dhorme, Eduard. A Commentary of the Book of Job. London: Nelson, 1967.

Dillmann, August. Hiob. Leipzig: Hirzel, 1891.

Driver, Samuel R. Notes on the Hebrew Text of the Books of Samuel. Oxford: Clarendon, 1890.

Driver, Samuel R. and George B. Gray. A Critical Exegetical Commentary on the Book of Job. 2 vols. International Critical Commentary. Edinburgh: T \& T Clark, 1921.

Duhm, Bernhard. Das Buch Hiob. Leipzig: J. C. B Mohr, 1897.

Ehrlich, Arnold B. Psalmen, Sprüche, und Hiob. Volume 6 of Randglossen zur hebräischen Bibel. Leipzig: J. C. Hinricks, 1918.

Ewald, Georg H. A. Commentary on the Book of Job. London: Williams and Norgate, 1882.

Feliks, Jehuda. Plant World of the Bible (In Hebrew). Massada: Ramat Gan, 1968.

Fisch, Harold. Tanakh Koren. Jerusalem: Koren, 1983.

Fohrer, Georg. Das Buch Hiob. Kommentar zum Alten Testament 16. Gütersloh: Gerd Mohn, 1963.

Gaab, Johann F. Das Buch Hiob. Tübingen: J. G. Cotta'schen, 1809.

Good, Edwin M. In Turns of Tempest: A Reading of Job with a translation. Stanford: Stanford University, 1990.

Gordis, Robert. The Book of Job: Commentary, New Translation, and Special Notes. New York: Jewish Theological Seminary of America, 1978. 
Guillaume, Alfred. “Arabic Background of the Book of Job.” Pages 106-127 in Promise and Fulfillment: FS for S.H. Hooke. Edited by F. F. Bruce. Edinburgh: T \& T Clark, 1963.

Habel, Norman C. The Book of Job: A Commentary. Philadelphia: Westminster Press, 1985.

Hahn, Heinrich. A. Commentar ueber das Buch Hiob. Berlin: J. A. Wohlgemuth, 1850.

Hakham, Amos. ספר איוב. Jerusalem: Mosad HaRav Kook, 1981.

Hirzel, Ludwig. Hiob. Leipzig: Weidmann, 1885.

Hitzig, Ferdinand. Das Buch Hiob übersetzt und erklärt. Leipzig: C. F. Winter, 1874.

Holmstedt, Robert D. "The Relative Clause in Biblical Hebrew: A Linguistic Analysis.” Ph.D. diss., University of Wisconsin, 2002. http://individual.utoronto.ca/holmstedt/HolmstedtDissertation.pdf.

Kissane, Edward J. The Book of Job. Dublin: Browne \& Nolan, 1939.

Melsheimer, Ludwig F. Das Buch Hiob. Mannheim: Schwan, 1823.

Noyes, George R. The Book of Job. Boston: James Monroe, 1838.

Perles, Felix. Analekten zur Textkritik des Alten testaments. München: Theodor Ackermann, 1895.

Pope, Marvin H. Job. The Anchor Bible 15. Doubleday: Garden City, 1986.

Pinker, Aron. "On the Interpretation of Proverbs 12:27." Journal of Biblical Textual Criticism 18 (2013): 1-8

. "Upon an Attack in Nahum 2:2." The Journal of Hebrew Scriptures 4 (20022003), Art. \#7, 4 pp. Online: http://www.jhsonline.org/Articles/article 29.pdf.

Rabinovitz, A. Z. and A. Abronin. איוב. Jaffa: Shushni, 1916.

Reichert, Victor E. Job. London: Soncino Press, 1960.

Schlottmann, Konstantin. Das Buch Hiob. Berlin: Weigand and Grieben, 1851.

Sayce, Archibald H. and Arthur E. Cowley. Aramaic Papyri Discovered at Assuan. London: A. Moring, 1906.

Tov, Emanuel. "Job 34." Pages 111-114 in vol. 1 of Outside the Bible, Ancient Jewish Writing Related to Scripture. Edited by Louis H. Feldman, James L. Kugel, and Lawrence H. Schiffan. Philadelphia, Jewish Publication Society, 2013.

Tur-Sinai, Naphtali H. כרך הספר. Jerusalem: Mosad Bialik, 1960. . The Book of Job. Jerusalem: Kiryath Sepher, 1967.

Umbreit, Friedrich W. C. Das Buch Hiob. Heidelberg: Mohr, 1824.

Aron Pinker, 11519 Monticello Ave., Silver Spring, Maryland, 20902, USA. Email: aron_pinker@hotmail.com 